\title{
PROFESSIONAL COMPETENCE AS A FACTOR OF THE EFFICIENCY OF THE ACTIVITY OF A PUBLIC SERVANT
}

\author{
Iryna Krynychna ${ }^{1}$, Volodymyr Gurkovskii ${ }^{2}$ \\ ${ }^{1}$ Doctor of Sciences (Public Administration), Professor, Professor Department of Public Management \\ and Administration, State University of Telecommunications, Kiev, Ukraine, e-mail: \\ krynychnairyna@gmail.com; ORCID: https://orcid.org/0000-0002-2823 \\ ${ }^{2}$ Doctor of Sciences (Public Administration), Professor, First Deputy Director of the Center for \\ Research in Public Administration Problems, 03057, Kyiv, Anton Tsedika st., 20, tel: 0675026900 , \\ e-mail: vladimir.gurkovskyi@gmail.com.ORCID: https://orcid.org/0000-0003-2021-5204
}

\begin{abstract}
The article reveals the concept and structure of the professional competence of civil servants, as well as their professional abilities. High-quality training of specialists in the field of state and municipal administration is a problem that is relevant both for modern higher education and for society as a whole. The quality of the activities of the next generation's Ukrainian political elite largely depends on how competent and prepared the graduates - future civil servants will be.

The introduction of new educational standards based on a competency-based approach has led to the need to improve the methodology and teaching methods in higher education. The modern concept of training civil service specialists places high demands on educational programs, in particular, on the development of professional competence of future civil servants provided for in them. It is important for the state that a student - a future civil servant - after graduation has a certain set of knowledge and skills, but one of the main requirements for a specialist is his desire and ability to quickly adapt to the new situation and navigate the modern information space, the ability to learn and develop professionally.

Studying the practice of functioning of state power and local self-government, the experience of the competition commissions that select applicants for vacant positions in the public service, as well as the experience of communicating with existing civil servants, students of professional retraining and advanced training programs of the state and municipal service, indicate that the current At present, the system of vocational education does not provide enough for students to form their civil servants - professional communicative competence.
\end{abstract}

In this regard, there is a need to find optimal ways to improve the work of the university in this direction, the need to develop a program that would purposefully form the professional communicative competence of students - future public servants.

Keywords: professional competence, civil service, civil servant, professionalization of civil servants, development of civil service, professional activity, professional activities of civil servants.

JEL Classification: D30, D73, D78

Formulas: 0; fig.: 0; tabl.: 0; bibl.: 24.

Introduction. The problem of the formation of professional communicative competence is reflected in many social, psychological, linguistic studies from different points of view. An analysis of the state of the issue in the theory and practice of higher pedagogical education shows that only certain issues of the formation of professional communication have been solved: the problems of modeling a professional orientation and the problems of modeling language activity are analyzed.

The modern professional community of state and municipal employees needs specialists who have received high-quality professional education, 
combining fundamental training and practical orientation of knowledge and competencies; specialists with a high level of moral qualities, erudition and culture, including communication (knowledge of the culture of thinking, rhetoric, techniques and methods of public speaking, the basics of communicative literacy, etc.).

Literature review. In scientific works devoted to the problems of professionalism and competence of public servants and the justification of the need for communicative knowledge and skills in the activities of a public servant Lipovskaya, N.A. (2015), "System-generated service: theoretical approaches" [1; 18], Karpa, M.I. (2014), "Functional Approach to the Concept of Positions of the Civil Service" [3], Pluscch, R.M. (2016), "Mistseve samovriaduvannia v umovakh detsentralizatsii vlady v Ukraini" [4], Kivalov, S.V. and Bila, S.V. (2002), "Orhanizatsiia derzhavnoi sluzhby v Ukraini" [7], Shpektorenko, I.V. (2009), "Profesiina mobilnist derzhavnoho sluzhbovtsia" [8], Yarmystyi, M.V. (2020), "Professional and social competence of civil servants" [9], Pashko, L.A. (2005), "Liudski resursy u sferi derzhavnoho upravlinnia: teoretyko-metodolohichni zasady otsiniuvannia" [10], Akimov, O.O. (2018), "The concept of the system genesis of the professional activities of public servants" $[2 ; 11 ; 12 ; 13 ; 14]$, Oluiko, V.M. (2004), "State service as a mechanism of public administration in civil society" [15], Bashtannyk, A.H. and Bashtannyk, V.V. (2012), "Organizational bases of formation of integrated systems of public management in the context of the European integration process" [16; 17], Serohin, S.M. (2003), "Derzhavnyi sluzhbovets u vidnosynakh mizh vladoiu i suspilstvom" [19], Surai, I.H.(2012), "Formuvannia ta rozvytok elity v derzhavnomu upravlinni: istoriia, metodolohiia, praktyka" [20], Linenko, A.F. (1998), "Professional activity and readiness for it" [22], Dukhnevych, V.M. (2002), "Psychological well-being of a professional as a condition of his effective activity" [23], Fedoryshyn, B.O. (1996), "Psychological and pedagogical bases of professional orientation" [24] and other researchers.

In the works of the above scientists, some pedagogical means of forming professional communicativeness are described and theoretically justified.

Paying tribute to the work done in this direction, it should nevertheless be noted that the means, ways and methods of forming the professionally significant communicative competence of future civil servants are insufficiently developed, which determines the relevance of this study.

Aims. The purpose of the study: to develop, justify and experimentally investigate the effectiveness of the model for the formation of professional communicative competence of future civil servants in the process of teaching the discipline "Public Administration". Object of study: professional training of future civil servants at the university. Subject of research: the formation of professional communicative competence of future civil servants in the process of teaching the discipline "Public Administration". 
Methods. To solve the tasks and verify the initial assumptions, a set of research methods was used, due to its subject, goals and objectives: theoretical the study and analysis of pedagogical, psychological literature, literature on the basics of communication, public relations management, public relations, training programs for specialists, educational and methodical documentation; modeling, designing, system analysis and synthesis to reveal the essence of the problem under study and the formation of the conceptual and terminological apparatus; empirical - interview, observation, questionnaire, testing, stating and control experiments; mathematical - quantitative methods for evaluating the results of experimental studies; statistical processing of quantitative data.

Results. Since the civil service is an institution of public service and, due to its organization and corporate cohesion, is one of the factors for stabilizing and ensuring the spiritual and moral security of citizens, the civil servant's competence is manifested not only in the quality of his job performance, but also includes his personal characteristics, features of his social behavior.

High-quality training of specialists in the field of state and municipal administration is a problem that is relevant both for modern higher education and for society as a whole. The quality of the activities of the Ukrainian political elite of the next generations largely depends on how competent and prepared graduates - future civil servants will be.

Being a comprehensive legal and social institution, the civil service ensures the fulfillment by the civil servants of the constitutional functions of the state, the activities of public authorities, other public bodies, individual public institutions, as well as the powers of persons who fill public positions in Ukraine.

Today, the civil service is interpreted "in the narrow sense as the performance by employees of their duties only in state bodies, and in the broad sense - as the performance by them of duties in all state organizations."

According to the regulatory framework, the professionalism of a civil servant is understood as "the acquired quality of personality's abilities that meets or exceeds professional requirements", i.e. referring to "deep and comprehensive knowledge and possession of practical skills in the relevant field of public service".

The competence of a civil servant is understood as "indicators characterizing professional knowledge, awareness and ability of a civil servant to effectively implement them in his official activities".

The modern professional community of state and municipal employees needs specialists who have received an elite (in terms of quality) professional education combining fundamental training and practical orientation of knowledge and competencies; specialists with a high level of moral qualities, erudition and culture, including communication.

Undoubtedly, the activities of public authorities and the public administration system of Ukraine affect the development and condition of society and the country as a whole. The quality of a public servant's activity depends on his professional competence as an integral characteristic that determines the ability to effectively solve professional problems and tasks. The specifics of the professional competence 
of an official in the sphere of state and municipal administration is determined by high complexity, social and professional significance. It is largely limited by the regulatory system of state and municipal services. Therefore, the issue of studying the professional competence of public civil servants, as well as its components, is so relevant and interesting $[1 ; 18]$

Competence in the field of public service is understood as indicators characterizing professional knowledge, awareness and ability of a public servant to effectively implement them in his official activities. [2]. Demonstrating professional competence, a public servant shows his professional suitability and compliance with public requirements and legal norms. A theoretical analysis of the literature made it possible to single out the following structure of professional competence of a civil servant: 1 . Cognitive component. Civil servants need to possess such professional knowledge and technologies as knowledge of organizational and managerial activities and the public sphere; updated knowledge about the features and innovative trends of public policy; knowledge of innovative technologies, including computer; understand the main directions of development of science and technology; understand the systemic nature of professional problems being solved and analytically approach them, as well as have critical thinking. In general, professional knowledge in the public service is understood as an integral and systematic set of knowledge in the field of state and law, government, political science, economics, sociology, psychology on the implementation of the powers of public authorities [2]. The implementation of the tasks set for government officials requires a clear adherence to theoretical knowledge with the final result embodied in the solution of official tasks.

2. The personal component. It includes personality traits, and character traits that help to effectively carry out their work, for example: hard work; self-confidence - the ability to defend one's own opinion; purposefulness; working capacity; ability to set goals; a responsibility; moral principles, beliefs, values, ethical standards that a person follows [2]; good faith; loyalty; tolerance (taking into account various points of view); stress resistance; initiative; discipline; diligence; perseverance, enterprise; humanism; self-development, the desire for self-improvement, continuous learning.

3. The communicative component. The professionalism of a public service employee reflects such individual characteristics of the sphere of communication as: the ability to adequately navigate in various situations of communication and interaction with other people (social insight); sociability; ability to competently build oral and written speech; knowledge of ethics and norms of business communication, rules of business correspondence and electronic communications; ability to conduct public speeches and negotiations (presentations); ability to work effectively in a team; [3]. the ability to provide necessary assistance and support to colleagues, ensuring success in work; social responsibility for the results of their work; business cooperation based on respect for people [4].

4. The activity component includes professional abilities, skills, ways of performing activities. The professional activity of a civil servant implies a good orientation in various situations, the ability to choose the best solutions to problems. 
Skills, on the other hand, save time on work and minimize mistakes and miscalculations.

A civil servant must work effectively both with individuals and with a team, be able to manage, initiate actions, set development directions and take responsibility; Be able to critically evaluate and strategically plan. In conditions of hard work of public servants, flexibility is important - the dynamism of switching from one type of activity to another. In this field of activity, such skills and competencies as determining priorities and components of tasks are also necessary; ability to delegate authority; to find new approaches and solutions to professional problems (innovation); result orientation; focus on quality (doing the work carefully, carefully, in accordance with the standard); adaptability, readiness for change; management and coordination (knowledge, resources, personnel, technologies), i.e. managerial competence [5].

Possession of managerial competence is especially necessary for public servants in leadership positions. It also includes the ability to plan professional activities and predict results (vision of development prospects); the ability to organize the process of setting and solving professional problems and create the necessary conditions for performers; the ability to provide and maintain feedback, control the results of work and the implementation of the task [4].

In addition, the above components of competence should be supplemented with the most important professional abilities of state and municipal employees, which are necessary for effective professional activity. [6]. These include: a) developed, morally oriented intellectual abilities; b) systematic self-development, education, advanced training; c) the ability to set strategic goals (analytical ability); d) activities to improve the functioning of the apparatus of the local government; e) the ability to effectively communicate with people, to persuade, to lead; e) prompt response to changing conditions and factors; g) control and management of their behavior in stressful situations, i.e. volitional, intellectual and emotional resistance to stressors; $h$ ) the ability of the organization to implement decisions (managerial abilities); s) continuous improvement of health and improvement of athletic form; c) high performance and competitiveness [7].

The resultant-targeted basis of the competency-based approach is competencies and competencies.

1) competence - the concept of systemic and multicomponent $[2 ; 11 ; 12 ; 13 ; 14]$;

2) competence combines the intellectual and skill components of education, knowledge, skills, and experience that ensure the implementation of professional activities (i.e., a specialist becomes competent, receiving information, acquiring knowledge and practical experience);

3 ) in the formation of a competent person, the education sector plays a paramount role [8];

4) competence is formed in the activity [15];

5) the concept of competence is broader than the total idea of acquired knowledge, skills, as it not only includes them, but also involves their effective use to solve a certain range of problems $[9 ; 10]$; 
6) competence is always manifested subject to a value-based attitude to activities, personal interest, motivation $[16 ; 17]$;

7) in the structure of competence there are always at least three components theoretical, practical and personal [19].

In the light of the foregoing, competency is the level of ownership of a set of competencies, the degree of readiness for applying competencies in professional activities.

Competence is the ability to apply knowledge, skills, and personal qualities for successful activity in various problematic professional situations [20]. That is, competencies are some internal, potential, hidden psychological neoplasms (knowledge, perceptions, action programs, value systems and relationships), which are then revealed in the person's competencies as relevant, active manifestations.

Among universal competencies we rank the knowledge, understanding, abilities, skills and value orientations that are inherent in all graduates, regardless of the direction and profile of specialization [21]. To professional competencies, on the contrary, we include only those knowledge, understanding, abilities, skills and value orientations that are necessary for the implementation of professional activities in a specific field (we consider the field of state and municipal government). Based on this, universal competence is the level of ownership of the set of universal competencies, respectively, professional competence is the level of ownership of the set of professional competencies [22].

By professional competence of a civil servant, we mean, first of all, his educational level, special professional knowledge, abilities, general instrumental skills, as well as the ability of a civil servant to effectively implement them in his career, but at the same time we assume that all this reinforced by the personal and business qualities of a public servant, his general humanitarian culture, his ability to understand the world around him and, of course, communicative competence th.

Among the varieties of professional competence, practical (special), social, informational and communicative, psychological, etc. are distinguished. Communicative competence is considered as a system of internal resources necessary to build an effective communicative action in a certain circle of interaction situations; it is a combination of communicative abilities, communicative skills and communicative knowledge, adequate to communicative tasks and sufficient to solve them [23].

Areas of professional competence of a civil servant: 1. Professional activity, a) special competence - owning professional activity itself at a sufficiently high level, the ability to design one's further professional development; b) professional communication, social competence - possession of joint (group, corporate) professional activity, cooperation; c) communicative competence - possession of the methods of professional communication accepted in this profession; social responsibility for the results of their professional work. 2. Professional formation of the personality: a) personal competence - mastery of the methods of personal selfexpression and self-development, means of resisting personality deformations; personality development within the profession; readiness for professional growth; $b$ ) 
individual competence - mastery of the methods of self-realization and the ability to rationally organize one's work without overloading time and effort, to carry out work effortlessly, without fatigue and even with a refreshing effect; ability to individual self-preservation; non-commitment to professional development.

For a public servant whose activities are constantly intersecting with the activities of other people, communications allow organizing social activities and enriching them with new connections and relationships [24]. However, sometimes civil servants who are distinguished by a high level of professional knowledge, skills and abilities, possess the necessary erudition, but do not know the rules for interacting with other people, turn out to be completely helpless in the communication process, since "any communication is effective only when people interacting with each other with a friend, competent in this situation".

Analyzing various points of view regarding the structure of the professional communicative competence of a civil servant, we distinguished the following components of the content of communicative competence: cognitive, personalitymotivational and active. Thus, we define the professional communicative competence of a civil servant as based on communicative abilities, skills and knowledge, intellectually, personally and motivationally determined social and professional characteristics, allowing him to independently and responsibly carry out effective and adequate communicative actions in a certain range of situations of interaction in professional activities.

In our understanding, the formation and improvement of the level of professional communicative competence of a civil servant can be achieved only if cultural factors are taken into account. In our work, we adhere to the concept according to which the general culture is determined not only and not so much by a certain amount of basic knowledge necessary and sufficient for cultural selfdetermination of a person within a certain "middle" standard of a cultural person, how much by the person's intellectual potential to achieve this knowledge in optimal and effective ways.

It should be noted that the activities of the future civil servant in the space of modern communications are largely associated with the use of a huge number of texts (oral public speeches, informational articles, press releases, etc.), for which understanding requires not only knowledge of the language in which the text compiled, but also a certain amount of personal context. One of the conditions for the adequate understanding and interpretation of the text is, first of all, the corresponding level of personal cultural development.

Thus, the formation of professional communicative competence involves not only mastering the necessary set of knowledge, the formation of skills in the field of practical use of the language in the process of speech activity, but also the implementation of educational tasks for the formation of a socially active, professionally trained personality orientated in the modern world.

Conclusions. Thus, we can draw the following conclusions that the competence of a civil servant is manifested not only in the quality performance of his duties, but also includes his personal characteristics, especially his social 
behavior, and the formation and increase of the level of professional communicative competence of a civil servant can only be achieved subject to the cultural factor. It should also be noted that the purposeful formation of professional communicative competence necessitates the use of technology of professionally-oriented training, according to which it is necessary to build training and apply methods in which the entire educational process would be associated with the future professional activity of the student, and also determines the form of training - communicative learning.

Professional communicative competence is becoming a necessary part of the general cultural competence, which involves increasing the general humanitarian culture of the person, the formation of her high creative, philosophical and behavioral qualities necessary for inclusion in a variety of activities in general and in the activities of public servants in particular.

Speaking about the professional competence of a civil servant, we mean, first of all, his educational level, special professional knowledge, abilities, general instrumental skills, but at the same time, we assume that all this is supported by the personal and business qualities of a civil servant, general humanitarian culture, the ability to understand the world around us and, of course, communicative competence.

In addition, professional competence affects the efficiency of public servants, determines the success and competitiveness of employees, which ultimately contributes to their professional development and personal growth. It is completely obvious that each person is individual in personal, business and professional aspects, but the larger the set of professionally important qualities a public servant will possess, the better professionally. Thus, a public servant needs to be diversified, competent in many fields of knowledge, his profession and life in general.

\section{Author contributions. The authors contributed equally. \\ Disclosure statement. The authors do not have any conflict of interest. References:}

1. Lipovskaya, N.A. (2015), "System-generated service: theoretical approaches", [Online], available at: http://dridu.dp.ua/konf/konf_dridu/dums_konf_2015 /pdf/510.pdf (Accessed 19 Jan 2020).

2. Akimov, O.O. (2014), "Psychological aspects of corruption in public administration", Derzhavne upravlinnia: teoriia ta praktyka, [Online], vol. 1, pp. 181-188, available at: http://nbuv.gov.ua/UJRN/Dutp_2014_1_23 (Accessed 19 Jan 2020).

3. Karpa, M.I. (2014), "Functional Approach to the Concept of Positions of the Civil Service", Efficiency of State Management (text): Zb.nauk. LEADU NADU under the President of Ukraine, Vol. 40. pp. 432-440.

4. Pluscch, R.M. (2016), Mistseve samovriaduvannia v umovakh detsentralizatsii vlady v Ukraini [Local self-government in the conditions of decentralization of power in Ukraine], RIDNA MOVA, Kyiv, Ukraine.

5. Soroko, V. M. (2009), Kadrova polityka i derzhavna sluzhba: konspekt lektsii [Personnel policy and public service: lecture notes], NADU, Kyiv, Ukraine.

6. Obolenskyi, O. Yu.(2006), Derzhavna sluzhba [Public service], KNEU, Kyiv, Ukraine.

7. Kivalov, S. V. and Bila, S.V. (2002), Orhanizatsiia derzhavnoi sluzhby v Ukraini [Organization of the civil service in Ukraine], Yurydychna literatura, Odesa, Ukraine.

8. Shpektorenko, I.V. (2009), Profesiina mobilnist derzhavnoho sluzhbovtsia [Professional mobility of a civil servant], Monolyt, Dnipro, Ukraine. 
9. Yarmystyi, M.V. (2020), "Professional and social competence of civil servants", available at: http://cppk.cv.ua/122.php (Accessed 19 Jan 2020).

10. Pashko, L.A. (2005), Liudski resursy u sferi derzhavnoho upravlinnia: teoretyko-metodolohichni zasady otsiniuvannia [Human resources in public administration: theoretical and methodological principles of evaluation], Vyd-vo NADU, Kyiv, Ukraine.

11. Akimov, O. (2018), "The concept of the system genesis of the professional activities of public servants", Investytsiyi: praktyka ta dosvid, vol. 23, pp. 133-138.

12. Akimov, O. (2018), "Functional factors of the system genesis of the professional activities of civil servants", Investytsiyi: praktyka ta dosvid, vol. 24, pp. 68-74.

13. Akimov, O. (2019), "The robustness of the system of professional activity of public employees: systemogenescial context", Investytsiyi: praktyka ta dosvid, vol. 5, pp. 104-109.

14. Akimov, O., Karpa, M., Parkhomenko-Kutsevil, O., Kupriichuk, V., \& Omarov, A. (2020). Entrepreneurship education of the formation of the e-commerce managers professional qualities. Journal of Entrepreneurship Education, 23 (S1).

15. Oluiko, V.M. (2004), "State service as a mechanism of public administration in civil society", Upravlinnia suchasnym mistom, vol. 7-9 (15), pp. 64-70.

16. Bashtannyk, A.H. and Bashtannyk, V.V. (2012), "Organizational bases of formation of integrated systems of public management in the context of the European integration process", Naukovyi visnyk Akademii munitsypalnoho upravlinnia, vol. 4, pp. 15-26.

17. Bashtannyk, V. (2010), Transformatsiia derzhavnoho upravlinnia v konteksti yevropeiskykh intehratsiinykh protsesiv [Transformation of Public Administration in the Context of European Integration Processes], DRIDU NADU, Dnipro, Ukraine.

18. Lypovska, N.A. (2011), "Interpretation of the concept of "public service": methodological controversy", Derzh. upr. ta mists. Samovriaduvannia, vol. 3 (10), available at: http://archive.nbuv.gov.ua/portal/soc_gum /Dums/2011_3/11lnasmp.pdf (Accessed 19 Jan 2020).

19. Serohin, S.M. (2003), Derzhavnyi sluzhbovets u vidnosynakh mizh vladoiu i suspilstvom [Civil servant in relations between government and society], DRIDU NADU, Dnipro, Ukraine.

20. Surai, I.H.(2012), Formuvannia ta rozvytok elity v derzhavnomu upravlinni: istoriia, metodolohiia, praktyka [Design and development of the elite in public administration: history, methodology, practice], TsP "KOMPRYNT", Kyiv, Ukraine.

21. Korneshchuk, V.V. and Yavorskyi, S. Kh. (2003), "The problem of readiness for professional activity in modern research", Nauka i osvita, vol. 1, pp. 21-24.

22. Linenko, A.F. (1998), "Professional activity and readiness for it", Visnyk Odeskoho instytutu vnutrishnikh sprav, vol.2, pp. 168-170.

23. Dukhnevych, V.M. (2002), "Psychological well-being of a professional as a condition of his effective activity", Ph.D. Thesis, Psychology, Kyiv, Ukraine.

24. Fedoryshyn, B.O. (1996), "Psychological and pedagogical bases of professional orientation", Ph.D. Thesis, Pedagogy, Kyiv, Ukraine.

Received: January 28, 2020 